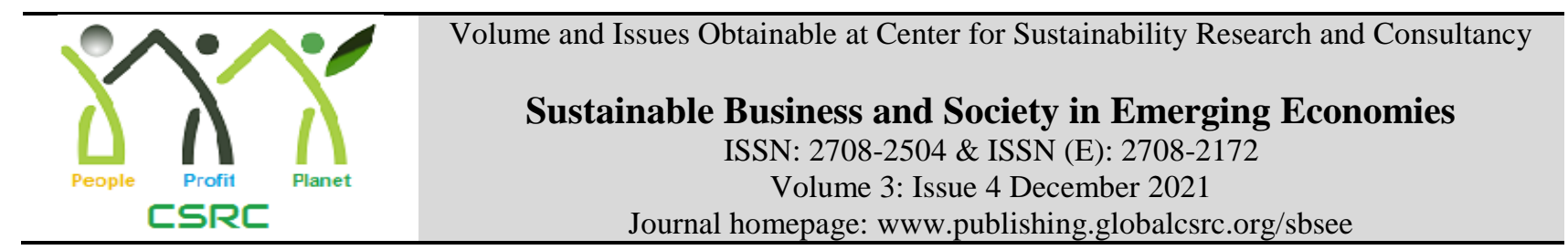

\title{
Human Resource Management Practices and Employee Performance in the Banking Sector of Pakistan: The Role of Islamic Work Ethic
}

Shakira Huma Siddiqui, Assistant Professor, Department of Applied Psychology, NUML, Islamabad, Pakistan

*Hira Salah ud din Khan, Associate Professor, School of Management, Jiangsu University Zhenjiang, The Peoples Republic of China

Nabeel Younus Ansari, Lecturer, Air University, Multan Campus. Pakistan

*Corresponding author's email address: hirakhan@ujs.edu.cn

\begin{tabular}{l}
\hline ARTICLE DETAILS \\
\hline History \\
Revised format: Nov 2021 \\
Available Online: Dec 2021 \\
\hline Keywords : Human \\
Resource Management \\
Practices (HRMPs), \\
Employee Performance (EP), \\
Islamic Work Ethics (IWE) \\
\hline JEL Classification \\
M1, M2
\end{tabular} ABSTRACT
Purpose: The present study aims to investigate the relationship between human resource management practices (recruitment and selection, training and development and performance appraisal) and employee's performance. Further, this study examines the moderating role of Islamic Work Ethics in the direct link mentioned above in the banking sector of Pakistan.

Design/Methodology/Approach: The data were collected from 256 employees working in the banking sector of Pakistan. To test the hypothesized relationships, multiple regression analysis was conducted.

Findings: The findings indicated the significant impact of human resource management practices (recruitment and selection, training and development and performance appraisal) on employee performance. Moreover, the moderating role of Islamic Work Ethics was also supported. This study found the Islamic Work Ethics strengthens the relationship between human resource management practices (recruitment and selection, training and development and performance appraisal), employee's performance.

Implications/Originality/Value This concludes that human resource management practices are essential for every organization that enhance the Employee's Performance. Further it is revealed Islamic Work Ethics moderates the relationship between human resource management practices and Employees Performance. Implications and future research for practice and directions are discussed.

(C) 2021 The authors, under a Creative Commons Attribution- Non

Commercial- 4.0

Recommended citation: Siddiqui, S.H., Khan, H.S. and Ansari, N. Y. (2022). Human Resource Management Practices and Employee Performance in the Banking Sector of Pakistan: The Role of Islamic Work Ethic. Sustainable Business and Society in Emerging Economies, 3 (4), 581-590. 


\section{Introduction}

Despite the increasing emphasis on the scholarship of human resource management (HRM) and its influence on individual and organizational performance (Vallina et al., 2021). Yet, there is significant gaps in understanding the mechanisms by which HRM contributes to sustainable and enhanced performance (Blom et al., 2020). In line with this, scholars conceded that Human Resource Management Practices (HRMPs) plays an essential role in the organization (Papa et al., 2018). Human Resource Management Practices comprise of different techniques, for instance, training and development, recruitment, compensation, rewards and performance (Brunetto \& Beattie, 2020; Shin et al., 2020). Scholars elaborated that recruitment is the process of identifying and attracting competent or eligible candidates to fill a vacant post (Hamza et al., 2021). Employee selection is linked with determining the applicants who best meet the job requirements from the recruitment pool (Wangui et al., 2021). Another HRMPs, i-e., training and development (TD) strengthens individual's expertise, competencies, and proficiencies, resulting to professional growth (Budhwar et al., 2019). Also, TD facilitates individuals to work efficiently that leads to professional growth (Blom et al., 2020). Similarly, Performance appraisal (PA) one of the HRMPs also impacts the employee's motivation through performance assessment (Kadiresan et al., 2015).

The ability, motivation and opportunities (AMO) framework (Jiang et al., 2012) serves as a theoretical support for the understanding the present model. Based on AMO framework (Jiang et al., 2012), employee performance (EP) is higher if the organizations assign tasks according to their abilities, that also motivates them and offers opportunities for promotion and enhancement of skills (Budur et al.,2021). However, limited studies have investigated the impact of HRMPs (recruitment and selection, training and development and performance appraisal) on EP (Blom et al., 2020). Moreover, some recent studies have examined the importance of Islamic Work Ethics (IWE) in the Muslim work contexts that serve as a guide for the employees to improve their performance at workplace (Aflah et al., 2021; AlArimi, Masrom, \& Mahmood, 2016). Thus, this study examines the role of HRMPs (recruitment and selection, training and development and performance appraisal) on EP and the moderating role of IWE in the link between HRMPs and EP.

\section{Hypotheses Development}

\section{Human Resource Management Practices and Employee Performance}

The concept of HRMPs is based on the idea that humans are considered as capital or most important resource that has no other alternative (Mat et al., 2021). Initially the concept of HRMPs was related to personnel management, and then it was replaced by personnel department/ administrative or administration department (Guest, 1997, 2017; Guest, Paauwe, \& Wright, 2013). The HRMPs (recruitment and selection, training and development and performance appraisal) are concerned with policies that maximize the organizational performance, effectiveness, organizational commitment, and quality of products/services (Guest, 1997, 2017; Peccei, Van de Voorde, \& Van Veldhoven, 2013). Moreover, HRMPs (recruitment and selection, training and development and performance appraisal) processes involve hiring of right individuals (Hamza et al., 2021). The hired employees with proper training is necessary so that they can perform well at the workplace (Dessler, Starke, \& Cyr, 2001; Goklas et al., 2021; Turner et al., 2021). Organizations by implementing the HRMPs (recruitment and selection, training and development and performance appraisal) at the workplace could enhance the AMO strategies in order to increase the satisfaction level of employees that in turn leads to higher productivity (Díaz-Fernández, López-Cabrales, \& Valle-Cabrera, 2020; Korauš, Kaščáková, \& Felcan, 2020; Nguyen, Yandi, \& Mahaputra, 2020). Effective HRMPs (recruitment and selection, training and development and performance appraisal) helps management to gain organizational productivity through recruitment selection, training and development, and performance appraisal (Armstrong \& Taylor, 2014; Shipton et al., 2005). Moreover, organizations seeks for right employees by adopting HRMPs (recruitment and selection, training and development and performance appraisal), to achieve organizational objectives. According to AMO theory, if the organizations during the recruitment and selection processes (RS), hire an individual according to the job requirement and based on the skills and abilities of the individuals, result is higher performance. In contrast, regular TD program in the 
organization also helps the management for the enhancement of employees' skills, capabilities, and results in higher organizational performance (Bhatti, Shah, \& Abbasi, 2021; Bhatti, Soomro, \& Shah, 2021; Purwanto \& Prasetya, 2021). On the other hand, Performance appraisal (PA) tool has been widely used for the performance assessment of employees; which is not only beneficial for the employees for their growth and development but also beneficial for the organizations to achieve productivity (Al-Jedaia \& Mehrez, 2020; Kadiresan et al., 2015; Kuvaas, 2006; Rana \& Singh, 2021; Ullah et al., 2021). In line with the discussion above, it is hypothesized that:

Hypothesis 1a Recruitment and Selection positively links with Employee Performance.

Hypothesis 1b Training and Development positively links with Employee Performance.

Hypothesis 1c Performance Appraisal positively links with Employee Performance.

\section{Islamic Work Ethics as a Moderator}

The word ethics is derived from the Greek dictionary 'ethos,' the attitude of individuals is reflected through the individual character in society and at the workplace (Aflah et al., 2021). Moreover, ethics is concerned with traditions, behaviors, social justice, and the goodness of society (Aflah et al., 2021). Scholars explained that work ethics consists of the rules and regulations to manage and supervise the behaviors of employees at the workplace (Husin \& Norhasniah, 2012). Given this, IWE is a set of ethical rules set by Islam derived from the Quran and the Sunnah, which guides all humanity and followers of Islam (Aflah et al., 2021). Moreover, IWE provides hope and guidelines to the individuals to demonstrate positive attitudes and behaviors at the workplace, i.e., teamwork dedication, social relations, creativity, and innovation which in turn leads to higher business prosperity (Aflah et al., 2021). Islamic ethical system enables individuals to reduce the negative attitudes and behaviors at the workplace, such as knowledge hiding, workplace incivility, and counterproductive work behaviors (Khan et al., 2018; Khan et al., 2019). Subsequently, by following the norms and values set by Islam in the form of IWE, employees demonstrate positive outcomes such as higher performance, organizational citizenship behavior, higher job satisfaction, and organizational commitment (Aflah et al., 2021; Khan, Zhiqiang, \& Naz, 2019; Raja et al., 2019). AMO framework (Jiang et al., 2012) states that motivation plays a vital role in demonstrating higher performance. Based on this notion, the present study contends that IWE work acts as a moderator in enhancing the EP. Individuals inspired by the teachings of Islam perform better as compared to employees who are at the low level of IWE. Thus based on the detailed literature and theory, this study proffers the following hypothesis,

Hypothesis 2a Islamic Work Ethics positively moderates the relationship between Recruitment and Selection and Employee Performance

Hypothesis 2b Islamic Work Ethics positively moderates the relationship between Training and Development and Employee Performance

Hypothesis 2c Islamic Work Ethics positively moderates the relationship between Performance Appraisal and Employee Performance

\section{Conceptual Framework}

Drawing on AMO theory (Jiang et al., 2012) present study explained the impact of HRMPs (recruitment and selection, training and development and performance appraisal) on EP. Further, this study examined the moderating role of IWE in the above-mentioned direct link. According to the AMO theory, the organizations either public or private, utilizes HRMPs to gain higher productivity (Kellner, Cafferkey, \& Townsend, 2019). According to Gerhart (2005), HRPMs influence the abilities of individuals through unbiased hiring, selection, and recruitment. The management motivates employees through performance-based remuneration and encourages team work (Beltrán-Martín \& Bou-Llusar, 2018). The management by implementing AMO framework enhances the EP by involving them in professional tasks (Beltrán-Martín \& Bou-Llusar, 2018). These three components of AMO (abilities, motivation and opportunities) are interlinked with each other and are required at the workplace for higher productivity (Mat et al., 2021). Moreover, this study contends that the work environment of the organizations in the form of the Islamic ethical system provides intrinsic motivation to the individuals, which results in higher performance. By infusing AMO theory, present study investigated the direct impact of HRMPs 
(recruitment and selection, training and development and performance appraisal) on EP. Further, it was also found that IWE serves as a moderating variable that helps to heighten the performance.

\section{Materials and Method \\ Population \& Sample}

The population of this study comprised of management and staff working in the banking sector of Pakistan. In order to minimize the common method bias, the Data was collected from multiple sources (Podsakoff et al., 2003; Podsakoff, MacKenzie, \& Podsakoff, 2012), EP was rated from immediate supervisors and HRMPs that were exercised in the organization and the questions regarding the IWE were gathered from subordinates. Three hundred and fifty (350) copies of the questionnaires were distributed to respondents at the workplace simultaneously to immediate officers and subordinates. Out of 350 survey, 256 pairs of questionnaires were received from the respondents (immediate officers and subordinates) which were properly filled by the respondents and formed the final sample size for further statistical analysis. The total response rate was $73.14 \%$.

\section{Measures}

Three dimensions of HRMPs (recruitment and selection, training and development and performance appraisal) were investigated in this study. All the scales used for this study were measured on 05-point Likert scale ranging from 1 "strongly disagree" to 5 "strongly agree." Recruitment and Selection were assessed with seven item scale developed by Singh (2004) and Lievens \& Chapman (2010). Training and Development were assessed with eleven item scale designed by Singh (2004) and Anne \& Gronholdt (2001). Performance Appraisal was assessed with seven item scale developed by Singh (2004). Islamic Work Ethics was assessed by sixteen item scale by Ali (1992; 1988). Employee Performance was measured with nine item scale developed by Tassema \& Soeters (2006).

\section{Results}

\section{Descriptive Statistics, Correlation and Reliability Coefficients}

Table 1: Descriptive Statistics, Correlations and Reliability Coefficients

\begin{tabular}{|c|c|c|c|c|c|c|c|c|c|c|c|c|}
\hline & & Mean & SD & 1 & 2 & 3 & 4 & 5 & 6 & 7 & 8 & 9 \\
\hline 1 & Gender & 1.09 & 0.28 & & $.20 * *$ & $.14^{*}$ & $.38^{* *}$ & $.13^{*}$ & $.13^{*}$ & $.19^{*}$ & $.19 *$ & $.11 *$ \\
\hline 2 & Age & 2.17 & 0.97 & & & $.47 * *$ & $.41^{* *}$ & $.19 *$ & $.17 *$ & $.19 * *$ & $.11 *$ & $.14 *$ \\
\hline 3 & Education & 4.00 & 1.05 & & & & $.49 * *$ & $.15^{*}$ & $.16^{*}$ & $.18^{*}$ & $.10^{*}$ & $.15^{*}$ \\
\hline 4 & WE & 4.01 & 1.50 & & & & & $.17 *$ & $.16^{*}$ & $.15^{*}$ & $.15^{*}$ & $.12 *$ \\
\hline 5 & RS & 3.40 & 0.77 & & & & & (.85) & $.48 * *$ & $.34 * *$ & $.45^{* *}$ & $.44 * *$ \\
\hline 6 & TD & 3.08 & 0.79 & & & & & & (.91) & $.60^{* *}$ & $.37 * *$ & $.37 * *$ \\
\hline 7 & PA & 2.85 & 0.86 & & & & & & & (.89) & $.47 * *$ & $.41 * *$ \\
\hline 8 & IWE & 4.10 & 0.56 & & & & & & & & $(.92)$ & $.48 * *$ \\
\hline 9 & EP & 4.32 & 0.45 & & & & & & & & & (.84) \\
\hline
\end{tabular}

Note: WE: Work experience; RS; recruitment and selection, TD; training and development, PA; performance appraisal, IWE; Islamic work ethics, EP; employee performance, $* * \mathrm{p}<.05, * \mathrm{p}<.01$

Table 1 demonstrates the mean, standard deviation, correlation values and alpha coefficients. The alpha coefficients of the scales used in the present study range from 0.88 to 0.92

(Exceeding the minimum of 0.70) indicating the reliability of the scales (Nunnally, 1978). As the demographic variables had significant impact on the study variables, thus we controlled the effects of these variable for further analysis. Moreover, the results indicates that the study variables that HRMPs were related to EP. Islamic Work Ethics was related to HRMPs and EP.

\section{Main Effects and Moderation Results}

Table 2: Main effects and Moderation Analysis

\begin{tabular}{|c|c|c|c|c|c|}
\hline Relationship & Coeff & SE & t-value & p-value & LL/UL \\
\hline Constant & 4.30 & .03 & 24.70 & .00 & $4.23 / 4.36$ \\
\hline IWE & .27 & .07 & 4.05 & .00 & $.13 / .12$ \\
\hline
\end{tabular}




\begin{tabular}{|c|c|c|c|c|c|}
\hline Interaction $(\mathrm{RS} \times \mathrm{IWE}) \rightarrow \mathrm{EP}$ & .13 & .06 & 2.17 & .02 & $.01 / .24$ \\
\hline Constant & 4.29 & .03 & 25.40 & .00 & $4.22 / 4.36$ \\
\hline TD & .11 & .04 & 4.27 & .00 & $.10 / .18$ \\
\hline IWE & .12 & .06 & 4.02 & .00 & $.12 / .14$ \\
\hline Interaction (TD x IWE) $\rightarrow$ EP & .17 & .07 & 2.53 & .01 & $.04 / .31$ \\
\hline Constant & 4.31 & .03 & 29.94 & .00 & $4.25 / 4.38$ \\
\hline $\mathrm{PA}$ & .14 & .04 & 3.29 & .00 & $.16 / .19$ \\
\hline IWE & .24 & .06 & 3.61 & .00 & $.15 / .08$ \\
\hline Interaction $(\mathrm{PA} \times \mathrm{IWE}) \rightarrow \mathrm{EP}$ & .11 & .07 & 2.49 & .02 & $.13 / .25$ \\
\hline
\end{tabular}

Note: RS; recruitment and selection, TD; training and development, PA; performance appraisal, HRMPs; human resource management practices, IWE; Islamic work ethics, EP; employee performance

Table 2 above shows the main effects and moderation effects. The first portion of this table indicates that interaction term (RS x IWE) has significant impact on EP. Thus H2a was supported. The second portion of the table 02 shows that the interaction term (TD x IWE) significantly impacts the EP. Thus, H2b was also supported. Lastly, the third portion, demonstrates that the product term (PA x IWE) has also significant impact on EP Thus, $\mathrm{H} 2 \mathrm{c}$ was also supported. To further elaborate the interaction effects of IWE, following interaction graphs were plotted.

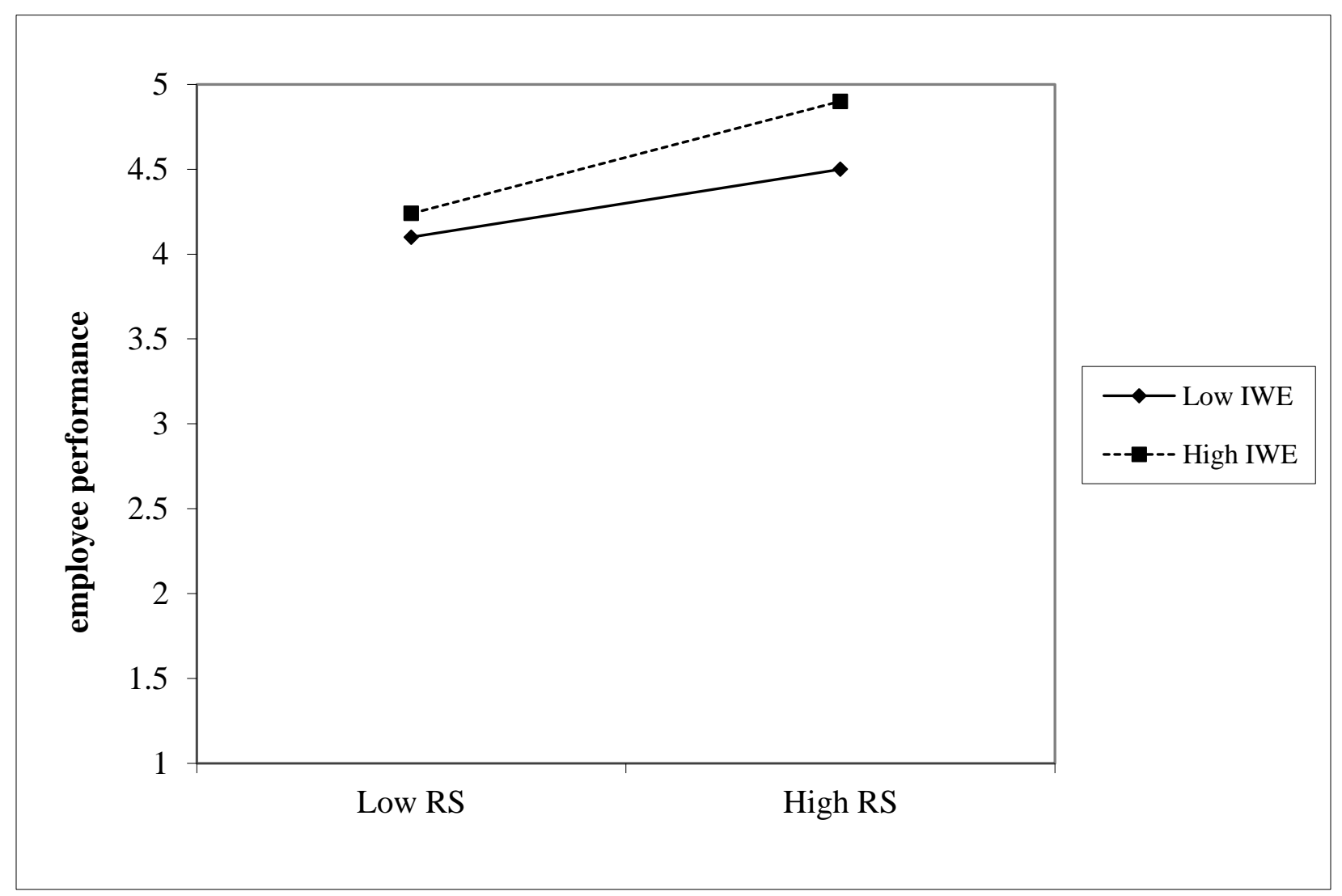

Figure 01: Interaction effects 


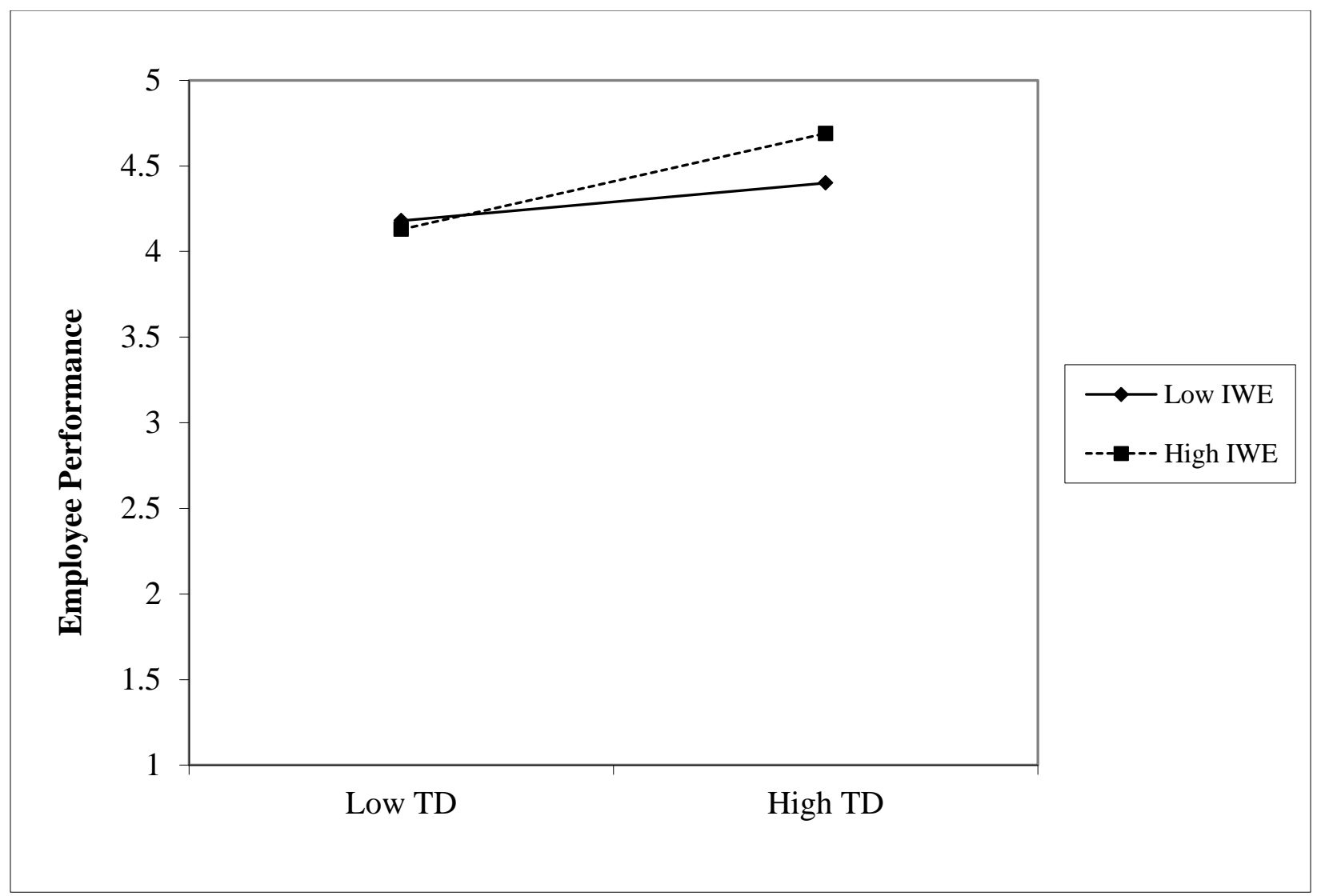

Figure 02: Interaction effects

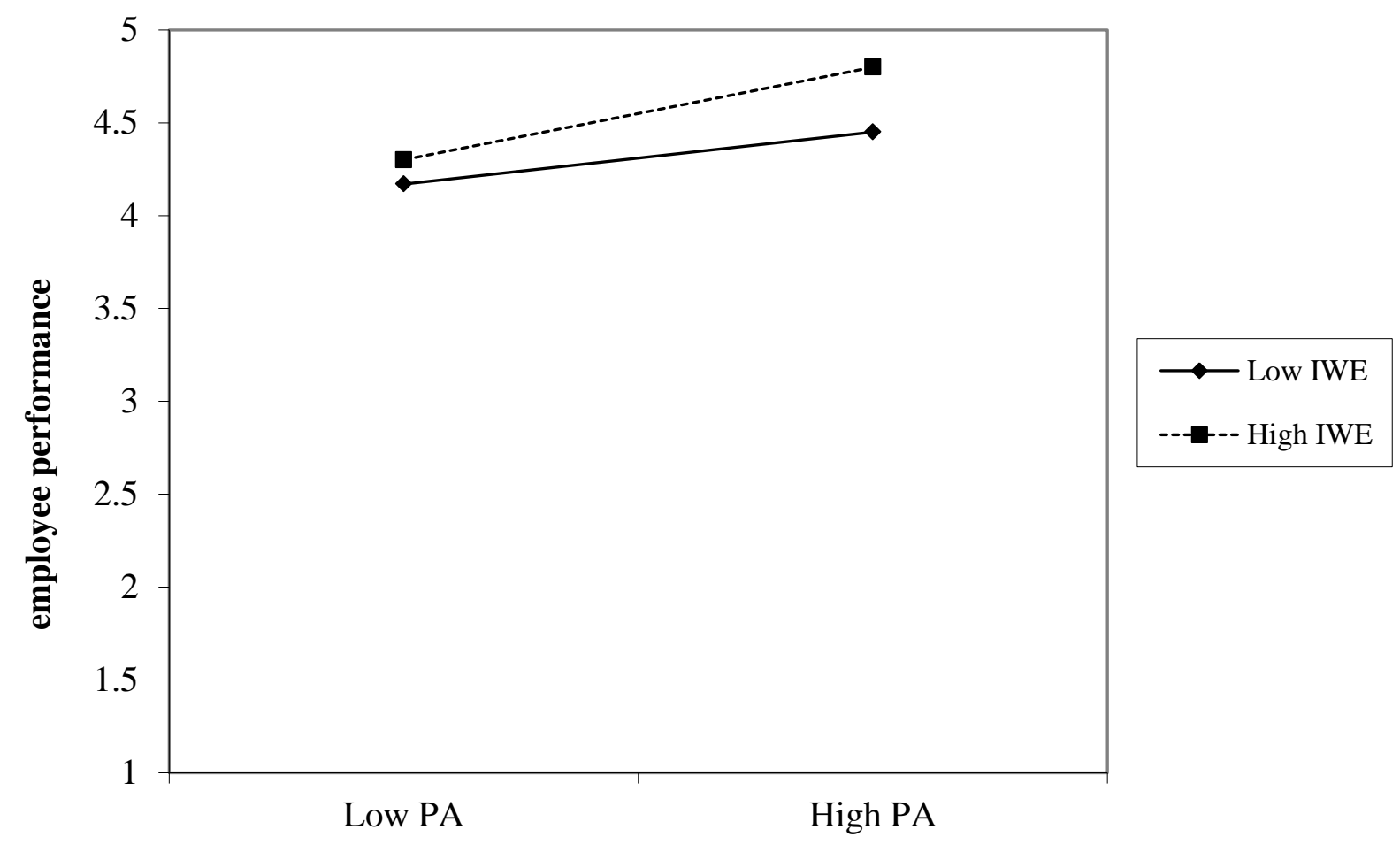

Figure 03: Interaction effects 


\section{Discussion}

By employing AMO theory, the present study investigates the direct influence of HRMPs on EP and the moderating role of IWE on the link between HRMPs (recruitment and selection, training and development and performance appraisal) and EP in the banking sector of Pakistan. It has been found that HRMPs (recruitment and selection, training and development and performance appraisal) directly influence the EP, which shows that implementation of proper recruitment and selection process, training and development, and comprehensive performance appraisal system leads to higher performance. Thus, if the organizations provide professional tasks to the employees according to their knowledge, abilities, the employees perform according to the expectations of the organizations. Similarly, providing opportunities to the individuals at the workplace led to higher performance. Results of present study are also supported by the findings of the earlier studies (Meijerink, Beijer, \& Bos-Nehles, 2021; Rodjam et al., 2020; Salas- Vallina, Alegre, \& López-Cabrales, 2021). Moreover, it has been found that IWE moderates the relationship between HRMPs (recruitment and selection, training and development and performance appraisal) and EP, which shows that a higher level of employees' IWE with the higher support of HRMPs (recruitment and selection, training and development and performance appraisal) by the management leads to higher performance. These findings support the AMO framework, which states that intrinsic motivation promotes the well-being of individuals, which further produces higher performance (Mat et al., 2021). The performance of banking employees improved by having strong faith in IWE provides them intrinsic motivation, which resultantly produces higher performance. These results are also supported by the findings of earlier studies (Khan et al., 2019; Khan, Zhiqiang, \& Naz, 2019). Overall, from the findings of this study it is concluded that a set of HRMPs (recruitment and selection, training and development, and performance appraisal) plays vital role in improving EP in banking Sector. Moreover, the findings elucidated that the Islamic ethical system in the form of IWE based on their belief and faith, is vital for the motivation of employees, motivated workforce performs higher and meets the expectations of the management.

\section{Conclusion}

This study investigated the impact of HRMPs (recruitment and selection, training and development and performance appraisal) on EP in the banking sector of the Pakistan. Further, the moderating impact of IWE was assessed in the direct link between the above mentioned relationships. The findings indicated the significant impact of HRMPs on the EP. Moreover, the results demonstrated that higher performance can be attained by implementing and practicing Islamic work ethics (IWE).

\section{Theoretical and Practical Implications}

The theoretical foundation for HRMPs (recruitment and selection, training and development and performance appraisal) and its association to EP was examined by employing the AMO framework, the impact of IWE as a moderator was further investigated in the banking sector of Pakistan. Moreover, the present study focused on finding out the impact of HRMPs on EP, drawing upon AMO framework in Asian country, Pakistan. To enhance the EP, the organisations could provide a platform for employees to learn professional, technical and educational skills. Also, the management of the banking sector could conduct training and workshops that engenders motivation and increases EP. Further, our study emphasized on the role of IWE which is one of the essential aspect in Muslim societies. Through, Islamic ways of working the financial sectors in the Muslim countries could improve their employee performance. Islamic work Ethic could be developed/increased arranging lectures based on spiritual and religious understanding of the work dynamics to boost the employees morale, which ultimately affects the behaviors and attitudes of the employees (Zhiqiang et al., 2021).

\section{Limitation and Future Directions}

The present study was conducted in the banking sector, same study can be conducted in other sectors. Further, different leadership styles with job designs could be studied for examining the employees work outcomes and productivity in the banking sector in future research. Moreover, the data collected for the 
present study is cross-sectional in nature, it would be better that future studies test the model by using the temporal separation method for the better understanding of employee's behavior at workplace.

\section{References}

Abstein, A., \& Spieth, P. (2014). Exploring HRM meta-features that foster employees' innovative work behaviour in times of increasing work-life conflict. Creativity and Innovation Management, 23(2), 211-225.

Aflah, K. N., Suharnomo, S., Mas'ud, F., \& Mursid, A. (2021). Islamic Work Ethics and Employee Performance: The Role of Islamic Motivation, Affective Commitment, and Job Satisfaction. The Journal of Asian Finance, Economics, and Business, 8(1), 997-1007.

Al-Arimi, A. A. A., Masrom, M., \& Mahmood, N. H. N. (2016). The Moderating effect of Islamic Work Ethics on the relationship between knowlege management capabilities and organizational performance at the private higher education institutions in Oman. Journal of Theoretical and Applied Information Technology, 94(2), 396-407.

Al-Jedaia, Y., \& Mehrez, A. (2020). The effect of performance appraisal on job performance in governmental sector: The mediating role of motivation. Management Science Letters, 10(9), 2077-2088.

Ali. (1992). The Islamic Work Ethic in Arabia. The Journal of Psychology, 126(5), 507-519.

Ali, A. (1988). Scaling an Islamic work ethic. The Journal of social psychology, 128(5), 575-583.

Anne, M., \& Grønholdt, L. (2001). Using employee satisfaction measurement to improve people management: An adaptation of Kano's quality types. Total Quality Management, 12(7-8), 949957.

Armstrong, M., \& Taylor, S. (2014). Armstrong's handbook of human resource management practice. Koganpage.

Beltrán-Martín, I., \& Bou-Llusar, J. C. (2018). Examining the intermediate role of employee abilities, motivation and opportunities to participate in the relationship between HR bundles and employee performance. BRQ Business Research Quarterly, 21(2), 99-110.

Bhatti, M. K., Shah, N., \& Abbasi, Z. (2021). An Investigation Of Training And Development Towards Employee Performance: An Empirical Approach From Nurses. Multicultural Education, 7(10).

Bhatti, M. K., Soomro, B. A., \& Shah, N. (2021). Training characteristics and employees' performance among the nurses in Pakistan. Journal of Economic and Administrative Sciences, ahead-of$\operatorname{print}($ ahead-of-print).

Blom, R., Kruyen, P. M., Van der Heijden, B. I., \& Van Thiel, S. (2020). One HRM fits all? A metaanalysis of the effects of HRM practices in the public, semipublic, and private sector. Review of Public Personnel Administration, 40(1), 3-35.

Brunetto, Y., \& Beattie, R. (2020). Changing role of HRM in the public sector. In (Vol. 22, pp. 1-5): Taylor \& Francis.

Budhwar, P., Pereira, V., Mellahi, K., \& Singh, S. K. (2019). The state of HRM in the Middle East: Challenges and future research agenda. Asia Pacific Journal of Management, 36(4), 905-933.

Budur, T., \& Poturak, M. (2021). Employee performance and customer loyalty: Mediation effect of customer satisfaction. Middle East Journal of Management, 8(5), 453-474.

Dessler, G., Starke, F. A., \& Cyr, D. J. (2001). Management: Leading people and organizations in the 21 st century. Prentice Hall Upper Saddle River, NJ.

Díaz-Fernández, M., López-Cabrales, A., \& Valle-Cabrera, R. (2020). Strength of HRM systems and perceived organizational support as determinants of employment relationships: The perspective of HR managers and workers' representatives. BRQ Business Research Quarterly, 2340944420977506.

Gerhart, B. (2005). Human resources and business performance: Findings, unanswered questions, and an alternative approach. Management revue, 174-185.

Goklas, A., Riyanto, S., Sihombing, J., AM, E. N., \& Sunarsi, D. (2021). Management Of Organizational Performance: The Role Of Human Resource Management Strategy. Jurnal Ad'ministrare, 8(1), 245-254. 
Guest, D. E. (1997). Human resource management and performance: a review and research agenda. The International Journal of Human Resource Management, 8(3), 263-276.

Guest, D. E. (2017). Human resource management and employee well-being: towards a new analytic framework: HRM and employee well-being: new analytic framework. Human Resource Management Journal, 27(1), 22-38.

Guest, D. E., Paauwe, J., \& , \& Wright, P. (2013). HRM and performance: achievements and challenges. Wiley.

Hamza, P. A., Othman, B. J., Gardi, B., Sorguli, S., Aziz, H. M., Ahmed, S. A., Sabir, B. Y., Ismael, N. B., Ali, B. J., \& Anwar, G. (2021). Recruitment and Selection: The Relationship between Recruitment and Selection with Organizational Performance. International Journal of Engineering, Business and Management, 5(3), 1-13.

Husin, W. N. W., \& Norhasniah, W. (2012). Work ethics from the Islamic perspective in Malaysia. European Journal of Social Sciences, 29(1), 51-60.

Jiang, K., Lepak, D. P., Han, K., Hong, Y., Kim, A., \& Winkler, A.-L. (2012). Clarifying the construct of human resource systems: Relating human resource management to employee performance. Human Resource Management Review, 22(2), 73-85.

Kadiresan, V., Selamat, M. H., Selladurai, S., Ramendran SPR, C., \& Mohamed, R. K. M. H. (2015). Performance Appraisal and Training and Development of Human Resource Management Practices (HRM) on Organizational Commitment and Turnover Intention. Asian Social Science, 11(24), p162.

Kellner, A., Cafferkey, K., \& Townsend, K. (2019). Ability, Motivation and Opportunity theory: a formula for employee performance? In Elgar introduction to theories of human resources and employment relations. Edward Elgar Publishing.

Khan, H. S. U. D., Zhiqiang, M., Abubakari Sadick, M., \& Ibn Musah, A.-A. (2018). Investigating the Role of Psychological Contract Breach, Political Skill and Work Ethic on Perceived Politics and Job Attitudes Relationships: A Case of Higher Education in Pakistan. Sustainability, 10(12), 4737.

Khan, H. S. U. D., Zhiqiang, M., Musah, A.-A. I., \& Udimal, T. B. (2019). Impact of perceived organisational politics on job attitudes in health sector of Pakistan: the moderating role of Islamic work ethic. Middle East Journal of Management, 6(6), 767-791.

Khan, H. S. u. d., Zhiqiang, M., \& Naz, S. (2019). Islamic work ethic and job outcomes: The mediating role of job satisfaction. International Journal of Advanced and Applied Sciences, 6(12), 7-17.

Korauš, A., Kaščáková, Z., \& Felcan, M. (2020). The impact of ability-enhancing HRM practices on perceived individual performance in IT industry in Slovakia. Central European Journal of Labour Law and Personnel Management, 3(1), 34-46.

Kuvaas, B. (2006). Performance appraisal satisfaction and employee outcomes: mediating and moderating roles of work motivation. The International Journal of Human Resource Management, 17(3), 504-522.

Lievens, F., \& Chapman, D. (2010). Recruitment and selection In A. Wilkinson, N. Bacon, T. Redman, \& S. Snell (Eds.),. In In A. Wilkinson, N. Bacon, T. Redman, \& S. Snell (Eds.), . Sage Publisher.

Mat, N. H. N., Mohamed, W. N., Salleh, H. S., \& Yusof, Y. (2021). HRM and Employee Significant Behavior: Explaining the Black Box through AMO Theory. Pertanika Journal of Social Sciences \& Humanities, 29(4), 2569-2589.

Meijerink, J. G., Beijer, S. E., \& Bos-Nehles, A. C. (2021). A meta-analysis of mediating mechanisms between employee reports of human resource management and employee performance: different pathways for descriptive and evaluative reports? The International Journal of Human Resource Management, 32(2), 394-442.

Nguyen, P. T., Yandi, A., \& Mahaputra, M. R. (2020). Factors that influence employee performance: motivation, leadership, environment, culture organization, work achievement, competence and compensation (A study of human resource management literature studies). Dinasti International Journal of Digital Business Management, 1(4), 645-662.

Nunnally, J. C. (1978). Psychometric theory (2nd ed.). New York: McGraw-Hill. 
Papa, A., Dezi, L., Gregori, G. L., Mueller, J., \& Miglietta, N. (2018). Improving innovation performance through knowledge acquisition: the moderating role of employee retention and human resource management practices. Journal of Knowledge Management. Peccei, R., Van de Voorde, F., \& Van Veldhoven, M. (2013). HRM, well-being and performance: A theoretical and empirical review. In HRM \& Performance: Achievements \& Challenges (J. Paauwe, D. E. Guest, \& P. M. Wright (Eds.) ed., pp. 15-46). Wiley.

Podsakoff, P. M., MacKenzie, S. B., Lee, J.-Y., \& Podsakoff, N. P. (2003). Common method biases in behavioral research: A critical review of the literature and recommended remedies. Journal of Applied Psychology, 88(5), 879-903.

Podsakoff, P. M., MacKenzie, S. B., \& Podsakoff, N. P. (2012). Sources of method bias in social science research and recommendations on how to control it. Annual Review of Psychology, 63, 539-569.

Purwanto, A., \& Prasetya, A. B. (2021). Did Coaching, Training and Development, Empowerment and Participation on School Employees Performance? Journal of Industrial Engineering \& Management Research, 2(2), 73-95.

Raja, U., Haq, I. U., De Clercq, D., \& Azeem, M. U. (2019). When ethics create misfit: Combined effects of despotic leadership and Islamic work ethic on job performance, job satisfaction, and psychological well-being. International Journal of Psychology.

Rana, S., \& Singh, S. (2021). Performance appraisal justice and affective commitment: examining the moderating role of age and gender. International Journal of Organizational Analysis, 30(1), 2446.

Rodjam, C., Thanasrisuebwong, A., Suphuan, T., \& Charoenboon, P. (2020). Effect of human resource management practices on employee performance mediating by employee job satisfaction. Systematic Reviews in Pharmacy, 11(3), 37-47.

Salas-Vallina, A., Alegre, J., \& López-Cabrales, Á. (2021). The challenge of increasing employees' well-being and performance: How human resource management practices and engaging leadership work together toward reaching this goal. Human Resource Management, 60(3), 333347.

Shin, D., Garmendia, A., Ali, M., Konrad, A. M., \& Madinabeitia-Olabarria, D. (2020). HRM systems and employee affective commitment: The role of employee gender. Gender in Management: An International Journal, 35(2), 189-210.

Shipton, H., Fay, D., West, M., Patterson, M., \& Birdi, K. (2005). Managing people to promote innovation. Creativity and Innovation Management, 14(2), 118-128.

Singh, K. (2004). Impact of HR practices on perceived firm performance in India. Asia Pacific Journal of Human Resources, 42(3), 301-317.

Tessema, T. M., \& Soeters, J. L. (2006). Challenges and prospects of HRM in developing countries: testing the HRM-performance link in the Eritrean civil service. The International Journal of Human Resource Management, 17(1), 86-105.

Turner, N., Barling, J., Dawson, J. F., Deng, C., Parker, S. K., Patterson, M. G., \& Stride, C. B. (2021). Human resource management practices and organizational injury rates. Journal of Safety Research.

Ullah, Z., Ahmad, N., Scholz, M., Ahmed, B., Ahmad, I., \& Usman, M. (2021). Perceived accuracy of electronic performance appraisal systems: The case of a non-for-profit organization from an emerging economy. Sustainability, 13(4), 2109.

Wangui, N. E., \& Felistus, M. (2021). Effects of Recruitment and Selection and Performance of private secondary schools in Nyeri County, Kenya. European Journal of Education Studies, 8(9).

Zhiqiang, M., ud din Khan, H. S., Chughtai, M. S., \& Mingxing, L. (2021). Re-Engineering the Human Resource Strategies Amid and Post-Pandemic Crisis: Probing into the Moderated Mediation Model of the High-Performance Work Practices and Employee's Outcomes. Frontiers in Psychology, 12, 1-10. 